\title{
THE FIFTH ANNUAL MEETING, 1976
}

The Fifth Annual Meeting was held in London on 6, 7 and 8 July 1976 under the Presidency of Professor W. LINFORD REES.

\section{Scientific Meetings}

During the morning of Tuesday 6 July Professor Rees chaired a discussion on Better Services for the Mentally $I l l$ at which the following papers were presented: 'An Introduction to the White Paper and Consultative Document', Dr J. E. McA. Glancy; 'The Long-Term Effect on the Service of the Implementation of the Government Proposals', Dr Brian Ward; 'An Analysis of the Difficulties in the Implementation of the White Paper', Dr T. H. Bewley.

In the afternoon the President was in the Chair for a symposium on The Problems of Overseas Trainees. The following papers were presented: 'The Performance of Overseas Doctors in the M.R.C.Psych. Examination', Dr Christine Hassall, Discussant: Professor K. Rawnsley; 'Problems of Overseas Psychiatrists in Training and in Examinations: A Consumer Point of View', Dr Farrukh Hussain, Discussant: Professor G. F. M. Russell; 'Communication Training as a Possible Remedy to the Overseas Doctors' Problems in Clinical Practice', Mr Christopher Candlin (Applied Linguistics Research Unit, Lancaster). Discussant: Professor G. M. Carstairs.

The Distinguished Guest Lecture was delivered by Dr Nathan KIINE (Rockland Research Institute, USA) on Wednesday 7 July; the subject was 'Trends in American Psychiatry', Dr A. J. Coppen proposed the vote of thanks.

On Thursday 8 July the morning session was devoted to parallel seminars as follows: 'A Clinical Assessment for Psychosurgery' Dr D. Kelly; 'Inpatient Treatment of Bowel Habit Disorder in Children', Dr D. A. Walk; 'Insomnia and its Management', Dr C. N. Chen, Dr J. H. Lacey, Dr L. K. Hso, Miss M. H. Hartmann; 'Life Events', Dr E. Paykel; 'Therapeutic Community Principles and their Relevance to Psychiatric Units in District General Hospitals', Dr P. O'Farrell, Dr F. Dirmeik; 'Family Therapy', Dr S. Leiberman, Dr R. Kalucy; 'Ethological Considerations in Mental Hospital Design', Dr J. Kellett; 'Some Epidemiological Aspects of Psychoneurotic Disorder', Professor A. H. Crisp; 'Clinical Applications of Grid Technique', Dr P. Slater; 'Aspects of Brain Damage', Dr P. Storey; 'Opiate Dependence and Crime', Dr P. D'Orban; 'Antidepressants and Depressive
Classification', Dr E. Paykel, Dr J. Parker; 'Case Conference of the Psychotherapy Department of St George's Hospital', Dr I. MacDonald, Dr P. O'Farrell, Dr G. Wooster; 'Sexual Dysfunction Clinic', Dr R. Kalucy; 'Management of Patients with Anorexia Nervosa', Professor A. H. Crisp, Mrs B. Harding; 'Aspects of Dementia', Dr J. Kellett.

In the afternoon at Session A the following papers were read: 'The Incidence of Schizo-Affective Psychosis and other Psychoses defined in various ways, in a series of Camberwell First Admissions', Dr I. F. Brockington; 'Neuroendocrine Identification of Depression', Professor Bernard J. Carrol; 'The Dementia of Dementia Praecox: An Investigation of the Incidence of Cognitive Impairment and Cerebral Atrophy in Chronic Schizophrenia', Dr Eve C. Johnstone; 'EEG Power Spectral Profiles in Schizophrenia', Professor G. W. Fenton; 'Tardive Dyskinesia in Patients Treated with Depot AntiPsychotic Drugs', Dr Alan C. Gibson.

At the parallel Session B (Chairman Dr P. Sainsbury) the following papers were read: 'Undetermined Deaths-Suicide or Accident', Dr T. A. Holding; 'The Sensory Filter and Schizophrenia', Dr Russell Meares; 'Mortality in Neurosis: An Investigation of Hypotheses', Dr A. C. P. Sims; 'Identification of Stressors in Industry', Dr W. B. Spry; 'Subliminal Stress and Anxiety', Dr P. J. Tyrer.

At the meeting of the Psychotherapy Section on 8 July Dr W. L. Wilson presented a paper entitled "Some Reflections on "Action" and "Encounter" Techniques in Relation to the Practice'.

At the meeting of the Forensic Psychiatry Section on 5 July Professor Anna Marie Roosenburg (Utrecht) presented a paper on 'Aspects of the Institutional Care of Offenders'.

\section{The General Meeting}

The President, Professor W. Linford Rees, in the Chair.

The Minutes of the previous meeting held in London on 8, 9 and 1o July 1975, having been published in News and Notes in June 1976 were approved as a correct record and signed.

\section{Obituary}

The Registrar, Dr MORRIs MARKoWE, announced with regret the death of the following members:

William Johnstone Barbour, Medical Superintendent, Kingsway Hospital and Consultant Psychiatrist, Derbyshire Royal Infirmary. 
Harry Conitzer, Consultant Psychiatrist, Long Grove Hospital, Epsom, Surrey.

William James Hamilton, Ladhope, I3I Wickham Terrace, Brisbane, Queensland, Australia.

Norman Crichton Horne, Community Mental Health Centre, Fredericton, New Brunswick, Canada.

Delfun Lewis, Consultant Psychiatrist, Whitchurch Hospital, Cardiff.

Charles MacDonald Ross, formerly Medical Superintendent, Hollymoor Hospital, Northfield, Birmingham.

\section{Annual Report of Council}

Members of the College

The current membership figures are:

$$
\begin{aligned}
& \begin{array}{lllll}
\text { Honorary Fellows. . } & \ldots & \ldots & \ldots & 44
\end{array} \\
& \begin{array}{lllllll}
\text { Fellows } & \ldots & \ldots & \ldots & \ldots & \ldots & 798
\end{array}
\end{aligned}
$$

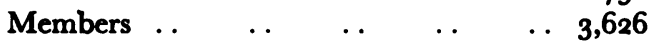

$$
\begin{aligned}
& \text { Affiliates } \ldots \text {. }
\end{aligned}
$$

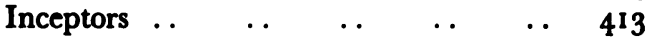

$$
\begin{aligned}
& \text { Corresponding Fellows .. } \quad \ldots \quad \text {.. } 44^{6}
\end{aligned}
$$

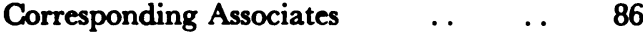

$$
\begin{aligned}
& 5,697
\end{aligned}
$$

During the year 43 new Fellows were elected.

\section{OFFICERS}

At the Annual Meeting in July 1975 the following took office:

$\begin{array}{ll}\text { President } & \text { Professor W. LINFORD ReEs } \\ \text { Vice-Presidents* } & \text { Dr W. WARREN } \\ & \text { Dr P. SAINSBURY } \\ \text { Registrar } & \text { Dr M. MARKOWE } \\ \text { Treasurer } & \text { Dr W. WARREN } \\ \text { Dean } & \text { Professor K. RAWNSLEY } \\ \text { Editor } & \text { Dr E. H. HARE } \\ \text { Librarian } & \text { Dr H. R. RoLLIN } \\ \text { Sub-Deans } & \text { Dr T. H. BeWLEY } \\ & \text { Dr C. P. B. Broox } \\ & \text { Dr A. SHAPIRO }\end{array}$

* Vice-Presidents are elected by Council after the Annual Meeting.

Council's nominations for Officers were made at the nominating meetings held in January and March and no other nominations were received. With the exception of the senior Vice-President, Dr W. Warren, the same Officers will therefore continue to serve during $1976-77$. It is relevant to note that in accordance with the Bye-laws Officers may only serve a maximum number of years. Professor Rawnsley who has been the Dean since the inception of the College will not be eligible for re-election in 1977; the other Officers will be eligible for re-election as follows: Professor W. Linford Rees, President -I year; Dr M. Markowe, Registrar-I year; Dr W. Warren, Treasurer-2 years; Dr E. H. Hare, Editor - 6 years; Dr H. R. Rollin, Librarian-9 years; Sub-Deans-Dr T. H. Bewley-I year; Dr C. P. B. Brook-3 years; Dr A. Shapiro-I year.

\section{MEMBership Examination}

The numbers entering for the Preliminary Test have continued to increase gradually and the pass rate over the past few tests has remained fairly constant.

\begin{tabular}{|c|c|c|c|c|}
\hline \multicolumn{5}{|c|}{ Preliminary Test } \\
\hline Date & & Entered & Sat & Passed \\
\hline November 1971 & .. & I I & 10 & 5 \\
\hline March $1972 \ldots$ & . & 14 & 13 & 9 \\
\hline October 1972 & . & 49 & 47 & 32 \\
\hline March I973 .. & $\ldots$ & 101 & 87 & 58 \\
\hline September 1973 & . & 119 & 118 & 107 \\
\hline March $1974 \ldots$ & .. & 224 & 201 & 94 \\
\hline September 1974 & . & 277 & 243 & 104 \\
\hline March $1975 \ldots$ & . & 343 & 307 & 119 \\
\hline September 1975 & . & 350 & 299 & 123 \\
\hline March $1976 \ldots$ & .. & 395 & 330 & 138 \\
\hline
\end{tabular}

The figures are as follows:

After the initial peak of entries for the Membership Examination in 1972/73 numbers fell as had been expected. Now, however, they are increasing gradually again, as follows:

\begin{tabular}{lrrrrr}
\multicolumn{6}{c}{ Membership Examination } \\
\hline \multicolumn{4}{c}{ Date } & \multicolumn{3}{c}{ Entered } & Sat & Passed \\
\hline March 1972 & $\ldots$ & $\ldots$ & 343 & 323 & 228 \\
November 1972 & $\ldots$ & 491 & 432 & 306 \\
May 1973 & $\ldots$ & $\ldots$ & 506 & 445 & 304 \\
November 1973 & $\ldots$ & 263 & 215 & 129 \\
May 1974 & $\ldots$ & $\ldots$ & 224 & 194 & 113 \\
November 1974 & $\ldots$ & 219 & 180 & 100 \\
May 1975 & $\ldots$ & $\ldots$ & 217 & 169 & 90 \\
October 1975 & $\ldots$ & 240 & 192 & 107 \\
May 1976 & $\ldots$ & $\ldots$ & 273 & 219 & N/A \\
\hline
\end{tabular}


A further Analysis of the Examination Results, prepared by Professor W. H. Trethowan and Dr Christine Hassall has been prepared and is being published in News and Notes. There was a very useful and interesting Examination Forum in the autumn at which examinees, tutors and examiners took part in a very wide exchange of views. In May the Examiners and Tutors met at Northampton during the Quarterly Meeting and again a very useful exchange of views and problems took place.

During the past five years the Membership Examination has become firmly and successfully established. All this time, with its initial difficulties and teething problems and great volume of work, Professor W. H. Trethowan has been Chief Examiner and he has given unstinted, untiring, and very expert service. He has now resigned and the College owes him a very great debt of gratitude. Professor Trethowan has been succeeded by Professor J. L. Gibbons.

The constitution of the Examinations SubCommittee has been formalized. Its function is to collect material for examination questions, to set examination papers, to consider examination results and make recommendations to the Court of Electors, to consider applications for the research option, to keep examination policy under review and make recommendations to the Court of Electors regarding possible changes in męthods of assessment. The SubCommittee has six members who serve for a maximum of three years; the Chief Examiner, the President and the Dean are ex-officio members. No specialist representation is built into the structure of the sub-committee but the Court of Electors will keep in mind the desirability of maintaining a spread of interests among its membership; the sub-committee will consult widely within the College and outside in the search for suitable material for the construction of examination questions.

\section{Approval of Hospitals and Units}

College Visitors continue to inspect hospitals and units seeking approval for purposes of general professional training for the Membership Examination. The Panels usually consist of three Visitors, often including a senior trainee, and as well as inviting written comment they consult widely during the visits. Subsequently detailed reports are submitted to the Central Panel of senior Visitors and their recommendations, together with summary reports are submitted to the Court of Electors for confirmation or otherwise. The visits have generally been found helpful and constructive and criticisms have often helped in acquiring additional provisions The following are the results of visits as at 1.5.1976:
A (Approved)

AS (Approved in specialty $1 \frac{1}{2}$ years)

$P$ (Approved improvement expected)

PS (Provisional approval in specialty; improvement expected)

U (Not approved)

12

(Last year's figures are given in brackets).

The results of 26 further visits are currently being considered.

Council, the Executive and Finance Committee, Standing and Special Commtrtees

Council and the Executive and Finance Committee have met regularly through the year and have been supported, advised, and stimulated by the Standing Committees, the Regional Divisions, the Specialist Sections and the Groups, as well as by the Special Committees which, representative of the appropriate interests within the College, have prepared evidence on a variety of topics.

The recommendations of the Special Committee on the Revision of the Bye-laws and Regulations were approved by Council for submission to the Annual General Meeting. The most important changes allow for statutory representation of trainees, the simplification of some election procedures, and the removal of the age limit for Inceptors. A Special Meeting convened at the time of the Quarterly Meeting in Northampton on 5 May 1976 approved the petitioning of the Privy Council to alter the Bye-law governing the maximum subscription rates which might be charged. There are no plans to increase the subscriptions in 1977 , but we have reached the maximum allowed and if inflation continues further increases may be needed at some time in the future.

Special Committees, under the Chairmanship of Dr Peter Scott, prepared evidence for the Home Office Advisory Group on the Law of Rape and on the Law Relating to Sexual Offences for the Criminal Law Revision Committee. A memorandum was submitted to the Committee of Inquiry into Special Education. Comments were submitted on the Report of the Committee of Inquiry into the Regulation of the Medical Profession (Merrison) and a questionnaire was returned to the Committee of Inquiry into Competence to Practise. Special Committees have also prepared evidence on the Responsibility of the Psychiatrist in Institutional Management and for the Committee of Inquiry into Mental Handicap Nursing and Care. 
A Special Committee of Council convened by Dr Brian Ward (Public Policy Committee), and with the following members: Professor W. Linford Rees (President), Professor K. Rawnsley (Dean; Education Committee). Dr P. G. Woolf (Forensic Psychiatry), Professor P. Graham (Child Psychiatry), Dr I. S. Kreeger (Psychotherapy), Dr A. Roith (Mental Deficiency), Dr Griffith Edwards, Professor J. K. Wing, Professor G. F. M. Russell (Manpower Sub-Committee), Professor R. Cawley (Research) and Dr J. M. Cuthill (Wales) prepared evidence on the White Paper 'Better Services for the Mentally IIl'; the Consultative Document 'Priorities for Health and Personal Social Services in England'; Health Circular (H.C. (76) I 8 'Joint Care Planning: Health and Local Authorities'; and the Consultative Document 'Proposed All-Wales Policies and Priorities for the Planning and Provision of Health and Personal Social Services from 1976-77 to $1979-80$ '. Professor Rees and Dr Ward addressed the All-Party Parliamentary Mental Health Group, who had all received copies of the Memorandum on the White Paper, and Professor Rees led a delegation of other bodies interested in mental health which met Mrs Barbara Castle, then Secretary of State for the Social Services. Throughout, emphasis has been placed on the need for ensuring that local authorities are made to carry out their obligations and that the best possible use will be made of the limited resources available. At the time this Report is being written arrangements are being made for College representatives to meet Mr David Ennals, the new Secretary of State for the Social Services.

Currently, evidence is being prepared for the Royal Commission on Gambling; the House of Commons Select Committee on Violence in the Family; and the Royal Commission on the National Health Service. Evidence is also being prepared on Addiction to Alcohol and it is hoped that this will be published by the end of the year. The Report of the (Butler) Committee on Mentally Abnormal Offenders is being studied.

Considerable time has been spent at Council, Committee and General Meetings considering the alleged abuse of psychiatry in the Soviet Union, and a report of a meeting between three senior Fellows of the College and Mr Leonid Plyushch, a dissident who was granted an exit visa, will be presented to Council in June and included in the Registrar's verbal report to the Annual General Meeting. Inquiries are going ahead about the possibility of sending an investigating commission to Russia jointly with the General Council of the Bar. These matters have been fully reported in the minutes of meetings published in News and Notes throughout the year, as has the exchange of correspondence on the subject.

The Education Committee (Chairman: Professor K. Rawnsley; Secretary: Dr T. H. Bewley) and its Sub-Committees have met regularly and Reports have been made to Council. Two memoranda prepared by the Manpower Sub-Committee have been approved by Council and published in News and Notes: " "Norms" for the Medical Staffing of a Psychotherapy Service for a Population of 200,000' and 'Manpower Requirements for Psychiatrists who Specialize in Alcoholism and Drug Dependence'. Unease has been expressed about certain aspects of the Hospital Practitioner Grade, and the SubCommittee are currently studying the non-consultant training grades. The Clinical Tutors Sub-Committee continues to meet regularly and a very successful conference was held in Liverpool; the possibility of College recognition of Clinical Tutors is being considered and proposals will be made to Council. The Nursing Sub-Committee has also met regularly and has helped in the preparation of evidence for the Committee of Inquiry into the Nursing and Care of the Mentally Handicapped. The Trainees Sub-Committee has considered many aspects of the College's work affecting the work of trainees and made recommendation to the Special Committee on the Bye-laws and Regulations; Trainees are widely represented on many of the College Committees. An Overseas Trainees Sub-Committee has been set up to advise the College, through the Education Committee, on the special problems of overseas trainees in psychiatry. A Library and Reading Lists Sub-Committee is preparing a book list and an Audio-Visual Aids Sub-Committee proposes to draw up a similar list. A Working Party is looking into the particular problems of Women in Psychiatry.

The Public Policy Committee (Chairman: Dr W. A. L. Bowen; Secretary: Dr Brian Ward) have considered many matters and its members have served on many Special Committees of Council, and participated in various discussions with the Department of Health and Social Security. Publication of the DHSS Review of the Mental Health Act is imminent and the comments of the College, already published in Newes and Notes, will then be reconsidered; in the meantime, at the request of the Department, the College's recommendations for the setting up of Commissions in England and Wales similar to the Mental Welfare Commission in Scotland were reviewed and endorsed. Other matters considered by the Public Policy Committee included the position of Occupational Therapists in the Mental Health Service, the Draft Gircular on Non-Accidental 
Injury to Children, the Sale of Hospital Land, the Voting Rights of Psychiatric Patients, Confidentiality, Information to the Police, and political dissidents. During the year Dr J. E. McA. Glancy retired as Departmental representative of the DHSS and he has been re-elected as a co-opted member of the committee; his valuable and untiring contribution to the work of this and other committees of the College, both formal and informal, has been of great assistance to the College and has been much appreciated.

The Programmes and Meetings Committee (Chairman: Professor K. Rawnsley; Secretary: Dr C. M. B. Pare) has organized a series of successful meetings through the year and in October 1975 joined with the Association of Directors of Social Services and the Royal College of General Practitioners in a one-day Conference which discussed 'Community Mental Health Services' (Proceedings are being published and will be available from the Nuffield Provincial Hospitals Trust). The Annual Meeting was held in London and Professor W. Linford Rees was inducted to the Presidency. The Distinguished Guest Lecturer was Professor Edward Sachar of New York and the Annual Dinner was held in the Great Hall at St Bartholomew's Hospital. Details of this and the other Quarterly Meetings are published in News and Notes. The Spring Quarterly Meeting was held at St Andrew's Hospital, Northampton, and the College's thanks and appreciation are due to Dr Tennent, the Chairman and Board of Governors, Mr A. G. Heritage, and all the staff there who worked so hard to make the meeting a splendid success. Thanks are also due to the Northamptonshire Area Health Authority for their hospitality. The Maudsley Lecture in November 1975 was delivered by Dr Anna Freud and was entitled 'Psychopathology seen against the Background of Normal Development'. The Blake Marsh Lecture in February 1976 was given by $\mathrm{Dr}$ W. A. Heaton-Ward and entitled 'Psychosis in Mental Handicap'.

The Library is still in store but it is hoped soon to acquire the capital to instal it at 17 Belgrave Square. In the meantime important journals are still being taken and subscriptions to others are being reconsidered in the light of their usefulness, their cost, and their availability elsewhere.

The British Fournal of Psychiatry and the Supplement, News and Notes, under the expert guidance of the Editor, Dr E. H. Hare, and Journal Committee, continue to appear regularly and punctually. During the year a new Assistant Editor, Dr Brian Barraclough, was appointed. Two further Special Publications are being prepared: Festschrift (in honour of the former Editor, Dr Eliot Slater) and Daniel
McNaughton: his Trial and the Aftermath; a second edition of Contemporary Psychiatry is also being prepared. In the interests of economy, when the present stocks are used up, the Journal will be printed on lighter weight paper.

The Research Committee (Ghairman (resigned : Dr B. Barraclough; Secretary (resigned : Dr M. Lader) has resubmitted the proposals for the Psychosurgery Research Project to the Medical Research Council following its rejection by the Leverhulme Trust. The M.R.C. has expressed interest and requested further information and the results of inquiries about the influence of the findings of such an investigation have now been forwarded to the Council and their decision is awaited. The Committee decided that it would not become directly involved with the planned research reported last year to examine and evaluate the present use of psychotherapy in the psychiatric services. The Committee is cooperating with CURB (Campaign on the Use and Restriction of Barbiturates) in the conduct of a Survey of a random sample of 100 Members of the College to obtain psychiatric information about the use of barbiturates.

\section{The Sections}

The Specialist Sections have been very busy and have often been expanding their interests. Through their representatives on Council, Standing Committees and Sub-Committees they have continued to exert a great influence on the work of the College.

The Psychotherapy Section (Ghairman: Dr I. S. Kreeger; Secretary: Dr P. O'Farrell) has continued to hold regular monthly scientific meetings. The speakers since the last Report include Dr P. M. Shaw and Dr P. Trower; Dr J. D. Sutherland; Dr I. Marks; Drs L. Kreeger, M. Davies, M. Pines and M. Crowe; Dr J. H. Kahn; Dr R. Gosling; Professor J. P. Watson and Dr B. Rosen; Dr R. D. Laing; Dr J. Bird; Dr B. Dick; and Dr P. L. G. Gallwey. The Section also joined with the Newcastle Regional Postgraduate Committee in organizing five two-day sessions of seminars. The Executive Committee has met on six occasions and matters discussed included the M.R.C.Psych. examination, psychotherapy manpower and the statutory registration of psychotherapists. There are approximately 2,000 members of the Section.

The Forensic Psychiatry Section (Ghairman: Dr P. Scott; Secretary: Dr R. Bluglass) arranged part of the scientific meetings during the Spring Quarterly Meeting at Northampton, and the Annual Meeting 1975, and a one-day Conference was held in November to discuss the Report on Mentally Abnormal Offenders (Butler Report). The Executive 
Committee has discussed many matters and contributed to the work of other committees, including the joint discussions with the DHSS on the admission of mentally abnormal offenders to hospital, and the new joint Advisory Sub-Committee with the Home Office which reviews all matters of joint interest between the College and the Prison Medical Service. Other matters considered include the training of forensic psychiatrists, forensic nursing and control units. There are approximately 475 members of the Section.

The Child Psychiatry Section (Chairman: Prof. P. Graham; Secretary: Dr I. Berg) organized a very successful two-day conference in Sheffield in November 1975; the speakers included Professor F. A. Jenner, Dr A. C. Woodmansey, Dr D. Schaffer, Dr K. Dawson-Butterworth, Dr P. Pinkerton, Dr B. Lask, Dr I. Kolvin, Dr A. R. Nicol and Dr R. Wrate. In March 1975 a one-day conference was held in London on 'Aggression and Anti-Social Behaviour in Ghildren and Adolescents', the speakers including Dr Ruth Harris, Dr M. Manning, Professor N. Berkowitz, Dr A. Storr, Professor M. Rutter, Dr D. Farrington, Mr W. Yule, and Dr R. Clarke. Liaison is being established with the British Paediatric Association and the Union of European Pedopsychiatrists. In addition to the many College committees on which representatives of the Child Psychiatry Section have served, a memorandum on the Psychiatry of Adolescence has been submitted to Council for approval and onward transmission to the DHSS, and a Working Party is preparing a document on the role of Child Psychiatrists in the Community. Steps are being taken to limit membership of the Section to bona fide child psychiatrists, but all those members of the College who are interested will be very welcome to attend scientific sessions. There are approximately 1,300 members of the Section.

The Mental Deficiency Section (Chairman: Dr Valerie Cowie; Secretary: Dr W. R. McKibben), has considered its title and decided to recommend no change. On 2 July 1975 the Section met at Borocourt Hospital, Reading, and in November at Queen Mary's Hospital, Carshalton; the speakers included Dr Maurice Fowles, Dr T. Loughnane, Dr J. Hammond, Dr J. Stern, Dr R. Harris, Mrs J. Partridge, Dr M. C. Liu and Dr E. Wright. During the Spring Quarterly Meeting in May 1975 the Section visited Princess Marina Hospital, Northampton. As well as the work done by its members on other College Committees, the Section has prepared documents on the Role of the Consultant in Mental Handicap and on the Present and Future Development of Mental Handicap Services, which was forwarded to the National Development Group. In addition representatives of the College led by Dr Heaton-Ward and Dr Shapiro met representatives of the DHSS to discuss the role of consultants in mental handicap. There are approximately 630 members of the Section.

\section{Grours}

The Social and Community Psychiatry Group (Chairman: Professor J. K. Wing; Secretary: Dr H. L. Freeman) has prepared two documents which were subsequently approved by Council. These are 'Psychiatrists and the Planning of Health and Social Services' which, together with a similar document prepared by the Scottish Division, is published in News and Notes; and 'Confidentiality of Psychiatric Data in Medical Information Systems'.

The Group for the Psychiatry of Old Age (Chairman: Dr Felix Post; Secretary: Dr Brice Pitt) is preparing a memorandum on 'Homes for the Elderly Mentally Infirm' for submission to Council and hopes to establish liaison with the British Geriatric Society through a Joint Working Party.

\section{The Drvisions}

The Divisions have been very active, especially the Scottish, Welsh, and Irish Divisions who have many direct dealings with their Health Departments and other national bodies and also specialist groups relating to the College Sections as well as to the Divisions. In future years it is hoped that the Secretaries of these Divisions will be able to include fuller reports of their activities in this Annual Report. A number of Divisions now organize their own self-supporting Annual Dinners and the President was able to attend those in Dublin and Cardiff. The Welsh Division publishes a stencilled News Letter which is regularly circulated to its members and other Divisions publish accounts of their meetings in News and Notes. Meetings of the Chairmen and of the Secretaries of the Divisions and Sections with Officers of the College have become a regular and very useful feature and are usually combined with a modest social occasion.

Joint Commitee on Higher Psychiatric Training

The Joint Committee has now appointed its own full time administrative secretary and is establishing routine procedures for visiting hospitals and units and for the approval of posts. Very soon all senior trainees will be asked to complete a questionnaire which will be the first step towards keeping a register of specialists and monitoring higher training. The position of research workers in relation to higher training is currently under consideration. 


\section{LiaIson with OTHER Bodies}

Regular meetings between representatives of the College and the DHSS on manpower and other topics have continued and have proved to be extremely useful; extra meetings have been held to discuss such matters as a code of practice for the management of violent patients, the admission of patients to hospital and the role and responsibilities of consultant psychiatrists in mental handicap. There are joint committees with the BMA, the Royal College of Physicians, the Royal College of General Practitioners, and members of the College serve on many national and international bodies. Members of other professional bodies are co-opted to serve on some College committees and their knowledge and expertise is very valuable and greatly appreciated.

\section{College Headquarters}

Although 17 Belgrave Square is not fully in use much has been achieved and it begins to look and feel more like a home for the College. The main problems outstanding depend on finance, and these are the installation of the Library (the shelving and books are in store), the conversion of the basement to house interchangeable lecture, social and catering facilities, and storage, and the furnishing of the President's office which currently houses one beautiful antique table and chairs, and the old carpet left by the previous owners of the house.

In June 1975 the caretaker's flat was completed and $\mathrm{Mr}$ and Mrs G. Brooks were employed as the College's caretaker and housekeeper and many other things besides. Through their goodwill and untiring efforts we are now able to hold many meetings at our headquarters. We can manage modest catering, and there is one room where members can sit and read. All this has been achieved at minimum cost and with maximum cheerfulness.

The Treasurer's Report gives details of the position regarding the Appeal but in addition the College is extremely grateful to its friends who have given gifts for the adornment of the College building. These include items of furniture, paintings, a sculpture and a beautiful chandelier which hangs in the entrance hall.

\section{Thanks}

There are many people who work for the College, give generously of their skills and their time, and further the interest of our patients and our members. To these, our Officers, Chairmen, Secretaries and members of Committees, Sections and Divisions; to Examiners, Clinical Tutors, Trainees, Visitors, Journal Assessors and many others we are extremely grateful.
To our President, Professor W. Linford Rees, we extend gratitude and appreciation for his tireless efforts, his gentle wit and firm grasp of our affairs and wish him well and congratulate him as he enters upon his second year of office.

The office staff work incredibly long but 'flexi' hours, as a team, under the superb leadership and guidance of Miss Natalie Cobbing. We are eternally grateful for such dedication.

\section{Supplementary Report}

The Registrar, Dr Markowe introduced the Report and read the following supplementary account of events which had occurred since the Annual Report went to press:

This report is really a supplement to the Annual Report which, of course, went to press two months ago. At that time the results of the Membership Examination held in May were not available but I can now tell you that 129 of the 219 candidates who entered were successful, a pass rate of $58 \cdot 9$ per cent.

The meeting with the Secretary of State, $\mathbf{M r}$ David Ennals, which will discuss the Consultative Document on Priorities in the Health Service and the Joint Care Planning Circular, will be held on 15 July.

A number of very important matters have been considered by the Council and the Executive and Finance Committee at their most recent meetings and $I$ am afraid that this Report may therefore be a little longer than it sometimes is.

The Report of the (Trethowan) Committee on the Role of Psychologists has now been published and the Special Committee of Council (under the Chairmanship of Professor Max Hamilton) which prepared comments on the interim report is considering it. Following the Report on St Augustine's Hospital and at the request of the Regional Health Authority, a Special Committee is considering various aspects of the use and administration of ECT, and the Research Committee has set up a working party to consider the feasibility of conducting a research inquiry into current practice in the use of EGT. Memoranda on Residential Homes for the Elderly (prepared by the Group for the Psychiatry of Old Age) and Violence in the Family (prepared by a Special Committee under the Chairmanship of Dr Peter Scott) have been approved and submitted to the appropriate bodies and will, subject to editorial agreement, be appearing in News and Notes.

At this week's meeting of the Executive and Finance Committee consideration will be given to the Report from the Public Policy Committee's Working Party on the Conduct of Committees of Inquiry, a Report from the Research Committee on the Report of the Committee (Brodrick) on Death 
Certification and Coroners, and to the Registration of certain overseas doctors in relation to our Membership Examination. Dr Woodforde-Williams, the Director, will be talking to the Committee about the work of the Health Advisory Service.

At the Quarterly Meeting held in Northampton in May the following Resolution was passed and will be sent to the WPA forthwith:

'The Royal College of Psychiatrists repeats its support for the steps taken by Council against abuses of psychiatry in the Soviet Union and requests Council to do all in its power at the next World Congress of the World Psychiatric Association to secure the passing of the following Resolution or one closely similar:

The World Psychiatric Association taking note of extensive evidence of the systematic abuse of psychiatry for political purposes in the USSR joins in the condemnation of those practices which has already been made by the British Royal College of Psychiatrists as well as other bodies.'

At its last meeting Council received the Report of the meeting with $\mathrm{Mr}$ Leonid Plyushch. The Registrar then read the Report to the meeting. The report has subsequently been published (News and Notes, September 1976) and released to the Press.

Dr Valerie Cowie, Chairman of the Mental Deficiency Section, read a statement to the last meeting of Council expressing the Section's serious concern at the crisis situation facing the mental deficiency services at the present time. There was a serious shortage of staff, too few training schemes to attract recruits and the few training posts that existed were too frequently used as service posts. There were few Senior Registrar posts and many consultant vacancies. Many existing consultants were subsequently overburdened with impossibly large in-patient loads. It was felt that every effort should be made to attract trainees. Uncertainty about the future of the Specialty and the erosion of ultimate consultant responsibility also affected recruitment. As various disciplines vied for autonomy, patients were at risk, scandals were exposed, reports published and consultants often made scapegoats for poor facilities and shortages. This is only a précis of a very full statement. Council recognized that other specialties were faced with similar problems but that in these the crisis situation was not so imminent. Council reaffirmed its view that Mental Deficiency should remain a specialty of psychiatry and a special committee, under the chairmanship of the President was set up to look into the whole problem.

\section{Annual Report of the Treasurer for the year ended 31 December 1975}

\section{Accounts}

The accounts for the year to 3 I December 1975 are presented on pages 12 to 16 and cover the College's first year of operations from its new headquarters at I 7 Belgrave Square, London SWI. The accounts are set out in a form different from that previously used and include a 'Statement of Source and Application of Funds' as recommended by the Institute of Chartered Accountants; 1974 figures have been restated so that they are comparable with those for 1975 .

The dominant features of the balance sheet are once more the cost of the new premises and the amount outstanding on the loan from Guinness Mahon \& Co. Strenuous efforts were again made throughout the year to raise more capital funds, including an appeal to the members. Some further progress has been made but the finances of the College remain a source of anxiety. Until additional large donations become available to pay off the loan, the expansion of the College activities including making full use of its new premises will have to be slowed down.

As indicated in the 'Statement of Source and Application of Funds' the liquid funds of the College were $£ 100,777$ less at 31 December 1975 than they were in 1974. $£ 39,737$ of this was spent on refurbishing and equipping the new premises and $£ 50,000$ was applied in the reduction of the loan from Guinness Mahon.

Normal operations of the College in 1975 resulted in a deficit of $£ 29$ compared with a surplus of $£ 44,397$ in 1974. Income from subscriptions and fees fell $£ 9,229$ to $£ 87,234$ and this was offset to some extent by an increase of $£ 1,898$ in other income. Establishment and administration expenses rose sharply from $£ 98,543$ to $£ 148,514$, an increase of 50 per cent; an analysis of these expenses is presented in Note 2 on the accounts. As will be seen, staff costs, postage, telephone and printing all showed particularly large increases. The grant from the Department of Health and Social Security towards expenses arising from the assessment of general professional training amounted to $£ 7,289$ compared with $£ 4,509$ in 1974 . The publications operations of the College had another satisfactory year, showing a surplus of $£ 6,575$ compared with $£ 4,830$ in 1974 . Details are provided in Schedule III.

Net income on the examinations account was $£_{1,121}$ compared with a deficit of $£_{1,515}$ in 1974 . As will be seen from Note 4 on the accounts, gross fees were slightly higher but expenses showed a 
large increase. The 1974 figures were affected by the refund of fees.

The operating results for 1975 underline the need to raise the rates of subscriptions substantially from 1976 .

The market value of investments at the end of 1975 was $£ 128,504$ compared with $£_{106,307}$ at the end of the previous year.

\section{Appeal Fund}

This was set up in 1971. By the end of 1974 some $£ 270,000$ had been subscribed to the fund and during 1975 a further $£ 105,54^{8}$ was subscribed, $£ 92,603$ by generous benefactors from outside the College and $£ 12,945$ from members in answer to the appeal. The latter included a number of sevenyear covenants so that further money will be received from this source in future years.

The debt to Guinness Mahon \& Co stood at $£ 428,405$ at the end of $1975(£ 520,938$ at the end of 1974). The net repayment of $£ 92,533$ was achieved despite an interest charge of $£ 60,191$ which was added to the principal amount of the loan. This crippling interest charge indicates the paramount importance of paying off the loan at the earliest possible date. For this reason a repayment of $£ 50,000$ from College funds was made in November 1975; it is hoped to recoup any redemption moneys paid from the general fund in due course, but this must depend on the successful outcome of the appeal.

\section{General}

This has been an uncertain year financially for the College. A bold step was taken by buying 17 Belgrave Square for the headquarters of the College; the alternative of hiring expensive and probably inadequate office accommodation, after the lease of Chandos House expired in December 1974, was not considered justifiable. It was unfortunate that the need to acquire these headquarters coincided with the very serious national recession, which meant that certain potential benefactors found themselves unable to help the College at this time. However, whatever the financial anxieties that are being faced, it needs to be borne in mind that the College had been given over $£ 375,000$ by the end of 1975 . A further $£ 40,000$ was received from the Wolfson Fund early in 1976, together with $£$ ro,000 from the Variety Club. A further $£ 30,000$ is promised from Wolfson in 1977 . Thus with this help, and other aid sought, the College can look forward with some confidence to meet its financial needs in the future.
Approval of the Annual Report and Accounts was proposed by Dr Warren, seconded by Dr William SARgant and carried nem con.

\section{Discussion}

Dr William Sargant expressed the hope that in future years more time at meetings might be devoted to the care of patients at home and less to the interests of political dissenters elsewhere.

A proposal by Dr H. Bourne that the word 'alleged' be removed from the sentence in the Annual Report, referring to dissenters, was not accepted.

Dr C. P. Seager, referring to the Report of the Committee of Inquiry into St Augustine's Hospital, hoped that Council would encourage discussion within the College of changing attitudes in the Health Service professions.

\section{Bye-laws}

Proposed amendments to the Bye-laws which had been circulated (together with consequent changes in the Regulations) were approved. (Proposed by Dr J. R. Hamilton, seconded by Professor K. RAWNSLEY and carried nem con).

\section{Auditors}

Messrs Turquands Barton Mayhew and Co were reappointed as the College's Auditors for 1976-77.

\section{Election of Honorary Fellows}

The following were unanimously elected to Honorary Fellowship:

Kathleen Jones, Professor of Social Administration and Social Work, University of York.

Henry P. Laughlin, President, American Psychiatric Association.

Anna M. Roosenburg, Professor, Dr Henri Van Der Hoevan Kliniek, Utrecht, The Netherlands.

David Stafrord-Clark, formerly Physician-inCharge, Department of Psychological Medicine, Guy's Hospital.

NikolaAs Tinbergen, Professor in Animal Behaviour, University of Oxford.

\section{Overseas Delegates}

The President welcomed delegates and representatives from kindred societies overseas. These were: Dr Henry Laughlin (American Psychiatric Association, American College of Psychiatrists, American College of Psychoanalysis); Dr C. M. Chung (Hong Kong Psychiatric Association); Dr 
C. Izadi (Psychiatric Society of Iran); Dr R・ O. Jones (Canadian Psychiatric Association); Dr G. C. Boral (Indian Psychiatric Society); Dr Margrit Fischer (Danish Psychiatric Association); Professor F. Rinald (Società Italiana di Psichiatria).

Professor H. Wijsenbeek (Israel Psychiatric Association) and Dr D. Farrukh Hussain (Pakistan Psychiatric Society) were unfortunately prevented from attending at the last minute.

The President also welcomed the many Members and guests from overseas attending the meeting. There were visitors from Australia, Greece, Kuwait, The Netherlands, Tanzania and the USA.

\section{Presentation of Prizes}

The Gaskell Medal and Prize was presented to Dr Alec Roy, of the Maudsley Hospital.

The Bronze Medal and Prize was presented to Dr RobIn MurRay, the Institute of Psychiatry.

Presentation of a Mace to the College

Dr Martin Cuthbert, former President of the Royal Medico-Psychological Association presented to the College a handsome silver Mace.

\section{Social Events}

The Annual Dinner was held in the Great Hall at St Bartholomew's Hospital. Dr M. M. WhITTET proposed the toast 'The Guests' and Dr Wilfrid HARDING replied. The toast of 'The Royal College of Psychiatrists' was proposed by Sir FERGuson Anderson and the President replied.

Members and their wives and husbands attended the first Reception at the new headquarters at 17 Belgrave Square, and had the opportunity of viewing the new portrait of Sir Martin Roth, the silver Mace presented by Dr Cuthbert and other gifts generously donated to the College.

Members and their wives or husbands were accompanied by Mrs W. LINPORD ReEs on visits to Hatfield House and to Greenwich to see the Cutty Sark, the Painted Hall, the Chapel and the Royal Naval Museum.

\section{A NOTICE FROM THE PRESIDENT}

The College is arranging a Reception at the Hyatt Regency Hotel on Thursday, I September, at $6.30 \mathrm{pm}$, for Fellows and Members from the United Kingdom and overseas who are attending the World Congress of Psychiatry in Honolulu. I have sent a personal letter and invitation to all those who are known to be going, but I am having to rely on information supplied by the World Psychiatric Association and we may not have located everyone. If you have not received my letter but would like to be at the Reception, please contact the College as soon as possible.

W. LINFORD REES

President 


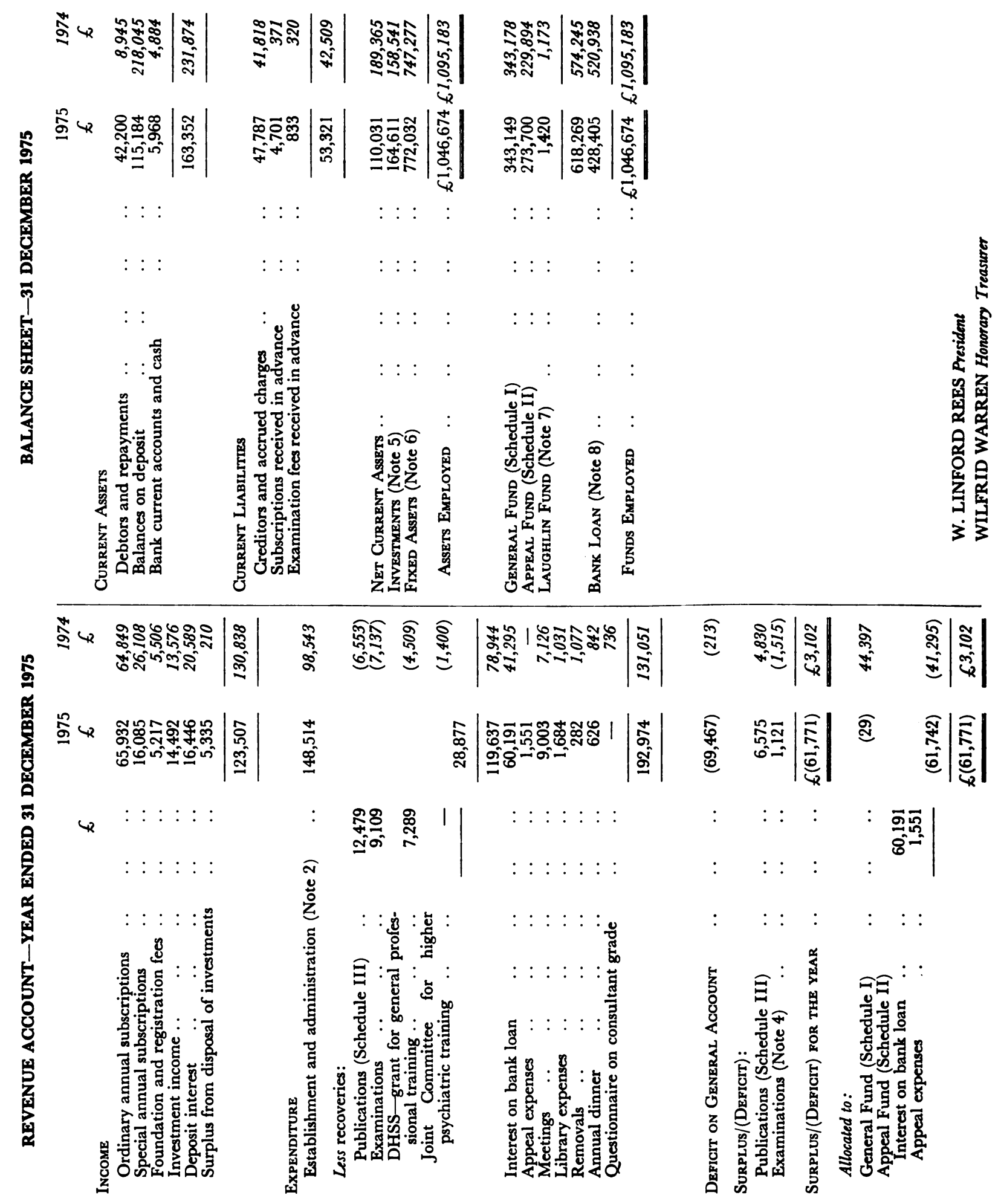




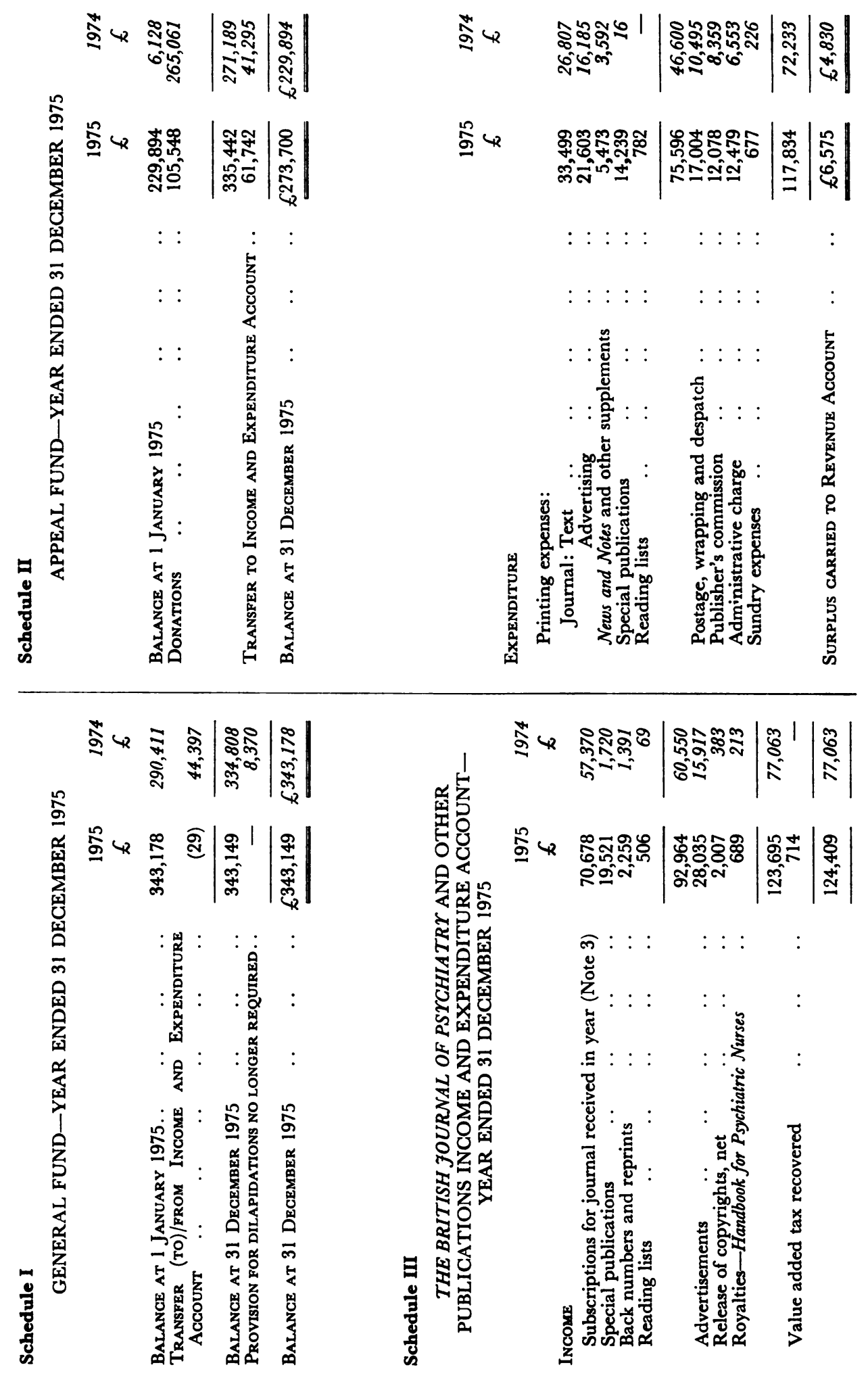



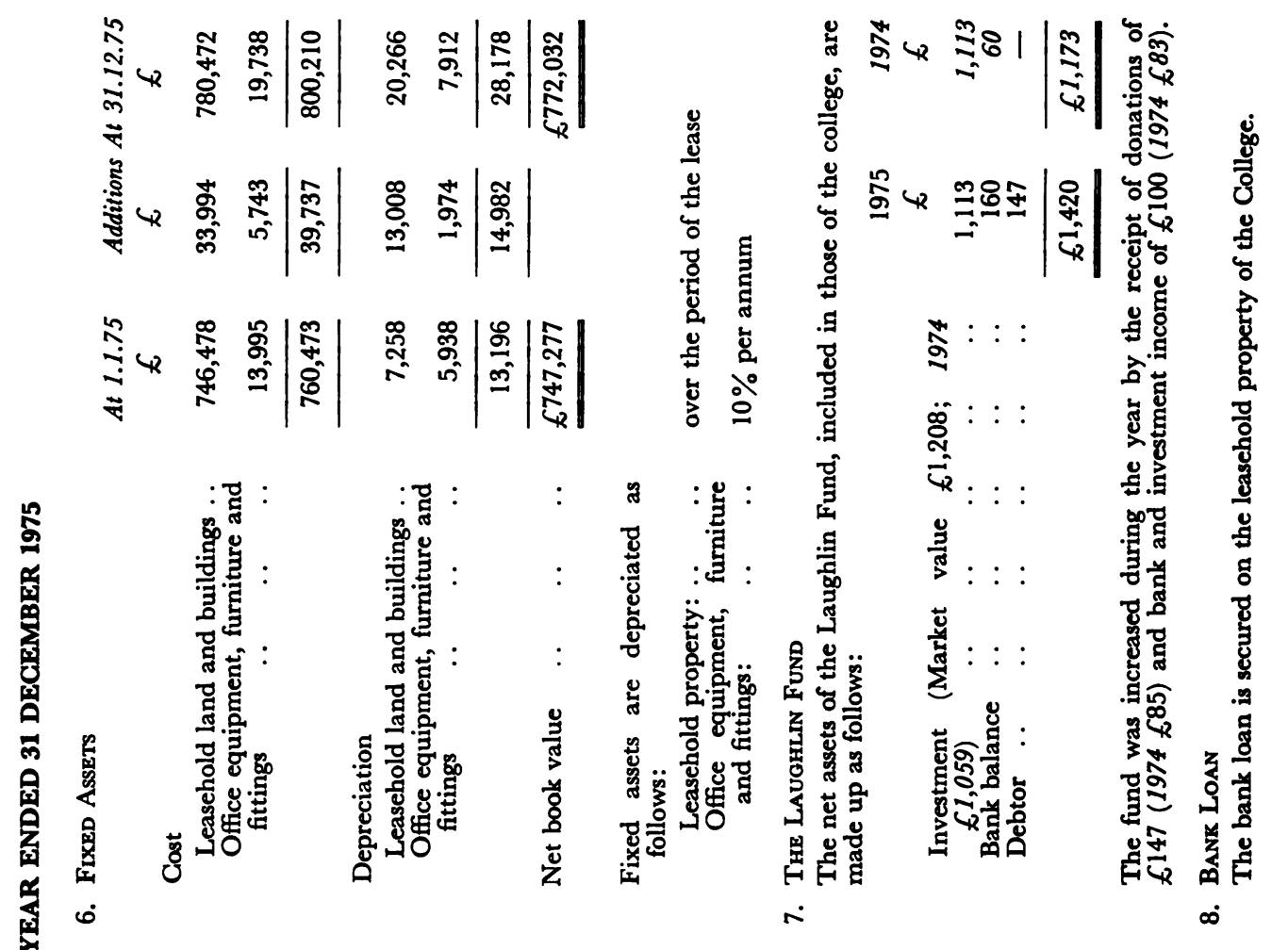

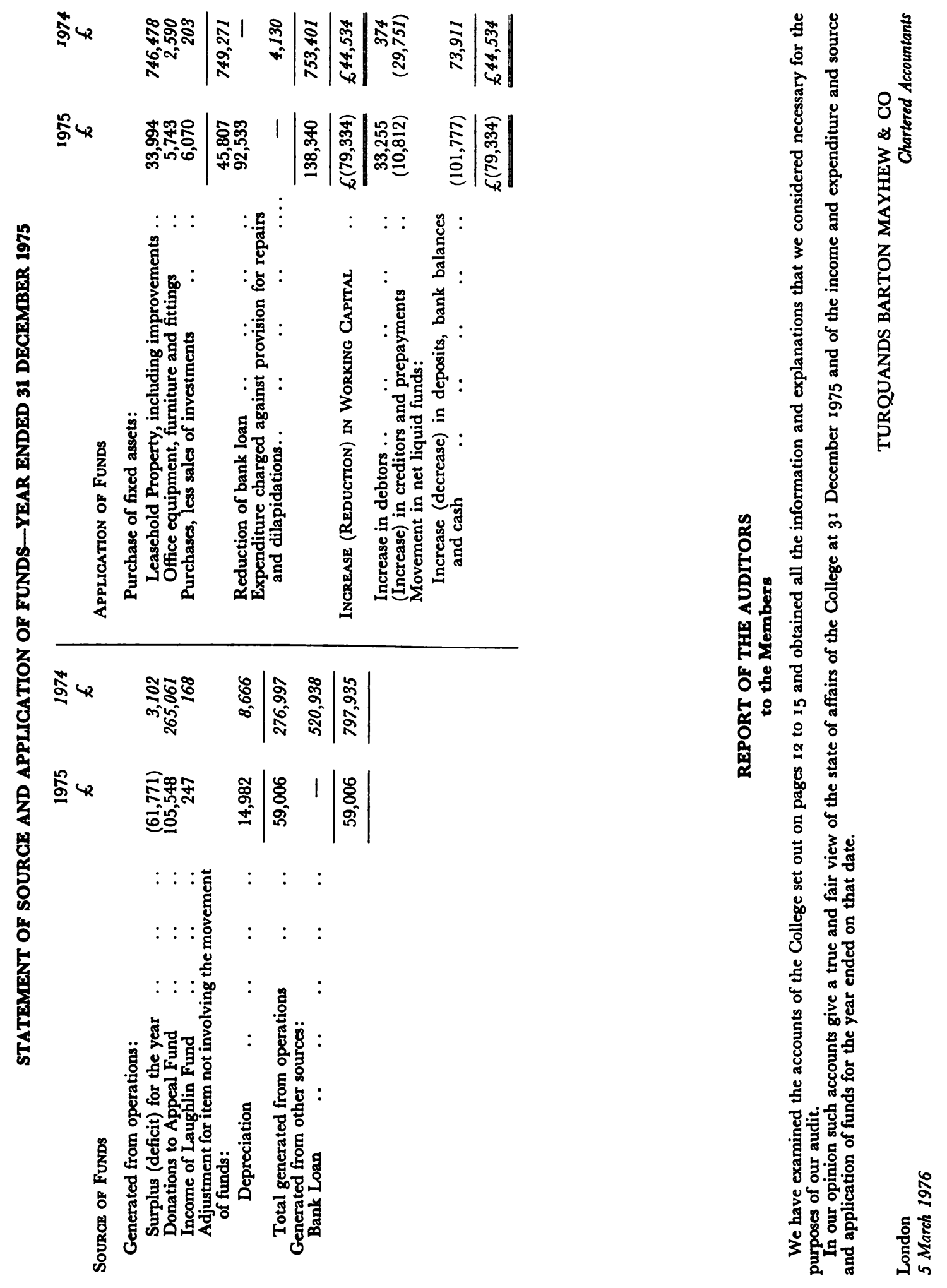

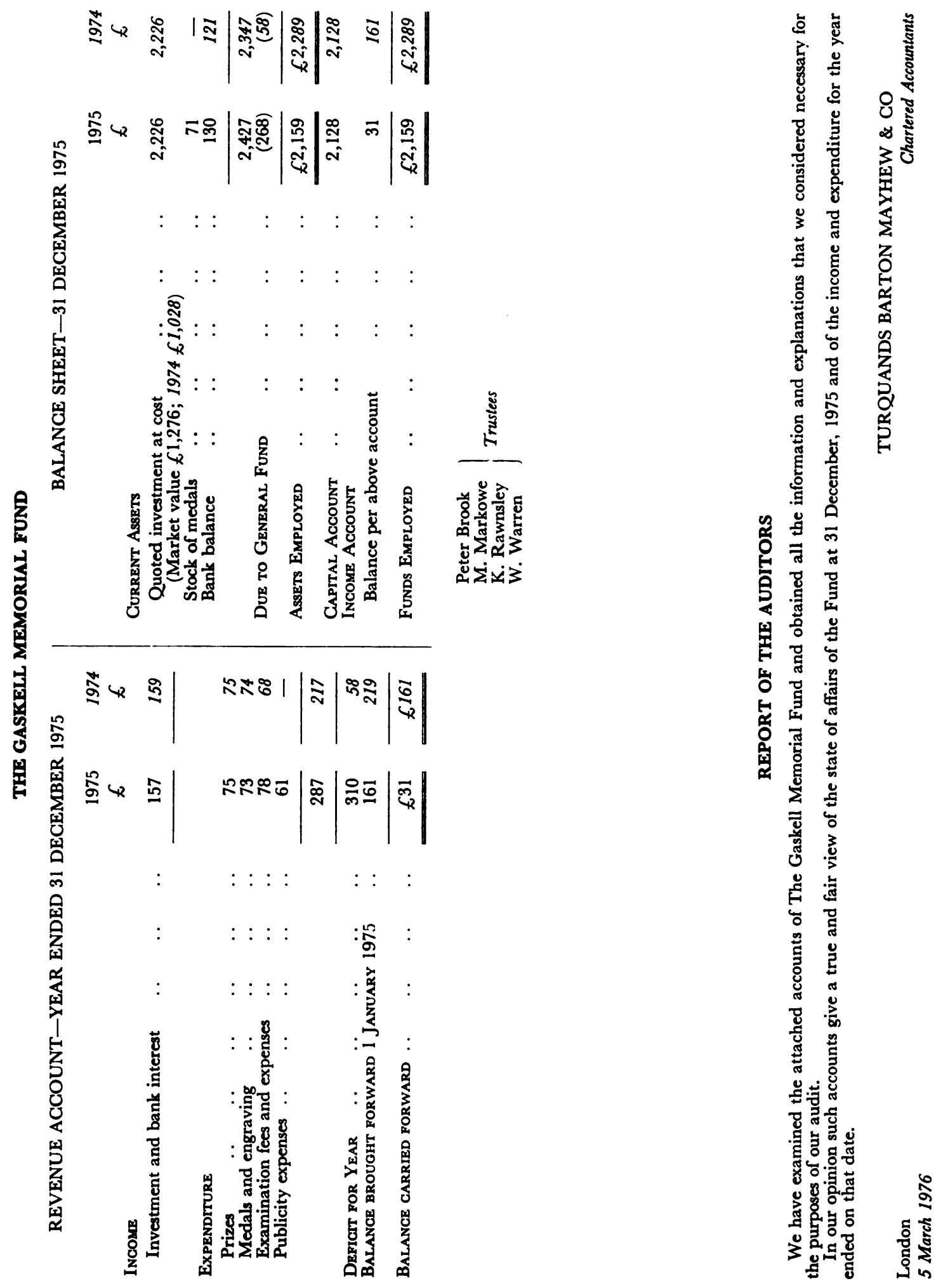